\title{
Tapping into Deep-Water Reservoirs to Overcome Antibiotic Resistance through Bacteria-Producing Unique Secondary Metabolites
}

\section{Farid Menaa*}

Director, Expert in Healthcare and Biosystems, Fluorotronics, Inc. and California Innovation Corp, San Diego, CA, USA

The marine microorganisms including bacteria, fungi, and microalgae have received increasing attention over past ten years due to their tremendous potential to produce new bioactive secondary metabolites $[1,2]$.

Indeed, marine microorganisms comprise a comparatively untapped reservoir of commercially valuable compounds with antibacterial, antiviral and anticancer properties [3], which attracts both academic and industrial organizations [4]. Marine microorganisms are particularly attractive because they fit the traditional pharmaceutical 'model' of a natural product drug source.

A number of antibiotics from marine microorganisms have been reported, including loloatins from Bacillus [5], Agrochelin and Sesbanimides from Agrobacterium [6], Pelagiomicins from Pelagiobacter variabilis [7]. Methicillin-resistant Staphylococcus aureus (MRSA) remains the most problematic gram-positive bacterium in public health not only because it is highly prevalent but also because it has become resistant to almost all available antibiotics except vancomycin and teicoplanin [8]. Recently, its susceptibility to vancomycin has decreased, and vancomycin-resistant $S$. aureus has increasingly been found in several countries. The evidence of MRSA resistance to vancomycin and teicoplanin, which are antibiotics of last resort, has resulted in the need for alternative antibiotics and chemotherapeutics. I am confident that tapping into deep-water reservoirs would be an asset to overcome antibiotic resistance through the identification and characterization of new bacteria-producing unique secondary metabolites.

\section{References}

1. Gerwick WH, FennerAM (2013) Drug discovery from marine microbes. Microb Ecol 65: 800-806.

2. Davidson BS (1995) New dimensions in natural product research: cultured marine microorganisms. Curr Opin Biotechnol 6: 284-294.

3. Gong Bin, Chen Yanping, Zhang Hong, Xiong Zheng, Zhang Yanqiu, et al (2014) Isolation, Characterization and Anti-Multiple Drug Resistant (MDR) Bacterial Activity of Endophytic Fungi Isolated from the Mangrove Plant, Aegiceras corniculatum. Trop J Pharm Res 13: 593-599.

4. Paul VJ (2003) Ecological roles of natural products of the Brazilian red seaweed Laurencia obtusa. Braz J Biol 63: 665-672.

5. Gerard J, Haden P, Kelly MT, Andersen R (1996) Loloatins A-D, A cyclic decapeptide antibiotic production in culture by a tropical marine bacterium. TetrahedromLett 37: 7201-7204.

6. Acebal C, Cañedo LM, Puentes JP, Baz F, Romero F (1999) Agrochelin, a new cytotoxic antibiotic from a marine agrobacterium. Taxonomy, fermentation, isolation, physicochemical properties and biological activity. J Antibiot 52: 983998.

7. Imamura N, Nishijima M, Takadera T, Adachi K, Sakai M, et al. (1997) New anticancer antibiotics, pelagiomicins produced by a new marine bacterium Pelagiobacter variabilis. J Antibiot 50: 8-12.

8. Witte W (1999) Antibiotic resistance in gram-positive bacteria: Epidemiological aspects. J AntimicrobChemother44:1-9.
*Corresponding author: Farid Menaa, Director, Expert in Healthcare and Biosystems, Fluorotronics, Inc. and California Innovation Corp, San Diego, CA USA, E-mail: dr.fmenaa@gmail.com

Received March 07, 2015; Accepted March 09, 2015; Published April 13, 2015

Citation: Menaa F (2015) Tapping into Deep-Water Reservoirs to Overcome Antibiotic Resistance through Bacteria-Producing Unique Secondary Metabolites. Pharm Anal Acta 6: e172. doi:10.4172/2153-2435.1000e172

Copyright: (C) 2015 Menaa F. This is an open-access article distributed under the terms of the Creative Commons Attribution License, which permits unrestricted use, distribution, and reproduction in any medium, provided the original author and source are credited. 